\title{
Passenger satisfaction with railway station service quality: An Ordinal Logistic Regression approach
}

\author{
Willy Kriswardhana ${ }^{1{ }^{*}}$, Nunung Nuring Hayati ${ }^{1}$ and Septiana Desy $\mathrm{R}^{2}$ \\ ${ }^{1}$ University of Jember, Department of Civil Engineering, Jember, East Java, Indonesia
}

\begin{abstract}
The objective of this paper is to examine the service quality dimensions and passenger characteristics and its effect on passenger's satisfaction on railway station. Jember Railway Station is a survey location where the questionnaires were spread. A total of 400 respondents who departure from Jember Railway Station were selected via convenience sampling method. The effects of characteristics and service quality items on the overall satisfaction were estimated using probabilistic approach. The thirteen service items extracted from Guidelines for Standardization of Railway Stations provide a representative framework of how passengers evaluate railway station service quality. This study illustrates how the probabilistic approach may be used for the direction of the effects of service quality and passengers' characteristics on the probability that a passenger presents higher level of overall satisfaction. Direction for future research is presented.
\end{abstract}

\section{Introduction}

Service quality is strictly linked to passenger's satisfaction [1]. Service quality is a specific judgment of services availed of while satisfaction is evaluated in broader terms [2]. Passenger's satisfaction on railway service quality has an effect on the frequency of the passenger travelling by train. Probability of passenger travelling by train will increase if the passenger feel satisfied on the railway service quality. Railway service quality is a very significant element for the travel effect, how to evaluate it is a difficult problem [3].

Period of using railway service has a positive relationship with behavior of railway staff. Frequency of travelling with train also has a positive relationship with passenger's

\footnotetext{
* Corresponding author: willy.teknik@unej.ac.id
} 
acceptance of arrival delay of train. The need of passenger's satisfaction is important to compete with other mode of transport [4].

According to DAOP IX Jember, the number of train passengers has rapidly increased since the improvement of service quality. The evaluation of service quality leads to customer satisfaction [5]. Satisfaction is a costumer fulfillment response, which is an evaluation as well as an emotion-based response to a service [6]. The perceived service quality is not only subjective, but also based on context that will likely different according to several factors [7].

While several research studies have been conducted on airline passengers perspective, little has been published on the perspective of railway station passengers especially in Asian country, include Indonesia. Hence, this study aims to examine the effect of railway station service quality on overall passenger satisfaction. Results offer a clearer perspective for railway station administrator, enabling them to identify passenger's behavior for better service.

In this context, the objective of this paper is to examine the service quality dimensions and passenger characteristics and its effect on passenger's satisfaction on railway station

\section{Methodology}

This study conducts a quantitative method with self-administered questionnaire in order to make sure the respondents know the conceptual of the questionnaire. A total of 400 questionnaires were sent out among respondents at the Jember Railway Station. Satisfaction scores (scaled 1-4) were collected for the overall satisfaction and for the satisfaction with several service attributes. In addition, background characteristics of respondents are also asked for, such as trip frequency, age, genders, level of education, income, trip origin and destination. The survey included attributes related to services railway station facilities. The items on railway station facilities were aligned with Guidelines for Standardization of Railway Stations, published by PT Kereta Api Indonesia (Persero).

This study focused on service attributes that are related to passengers overall satisfaction. First step of data analysis is testing the predictor variable includes service quality dimensions. Predictor variables were tested with validity and reliability test. Significance test is done by comparing the value of $r$ arithmetic with $r$ table, if $r$ arithmetic $>$ r-table and has positive value, then the variable is valid. While if $r$ arithmetic $<\mathrm{r}$-table, then the variable is invalid [8]. The measurement of the reliability of the question items by spreading the questionnaire to the respondents, and the results of the score measured the correlation between the answers scores in the same question items with Cronbach Alpha (a). A construct or variable is said to be reliable if it gives a Cronbach Alpha value $>0.70$ [8].

In the second step, an ordinal logistic regression model was estimated to examine service dimension and characteristics of passenger effects on satisfaction in overall. There are some advantages in using probabilistic model, especially when dealing with ordinal scales, categorical variable, and some cases where data do not satisfy linear regression assumptions [9]. 
Logistic regression generates an odds ratio associated with the value of each predictor. The probability of an event is defined as the probability of an arising outcome divided by the probability of an event not occurring. In general, the opportunity ratio is a set of opportunities shared by other opportunities. Because of the estimation coefficient expresses the relationship between logit and explanatory variables, their first interpretation pointing toward the effect on that probability passengers provide a higher level of satisfaction than lower level. In addition, the exponential coefficient can be used to evaluate its effect in terms of percentage change in odds [10].

Backward elimination was used as an alternative for model specification. As in many disciplines, null-hypothesis significance testing is commonly used. The test yields a statistic and probability (p-value). The null-hypothesis is rejected when the p-value is less than or equal to 0.05 or 0.01 in social science [11]. Theoretically, the p-value is a measure of continuous evidence, but in practice, it is usually trichotomized about to be very significant, slightly significant, and not statistically significant at the conventional level, with cutoffs at $\mathrm{p} \leq 0.01, \mathrm{p} \leq 0.05$ and $\mathrm{p}>0.10$. [12]. Most statistics handbooks present a rule of thumb of $0.1,0.05$ and 0.01 significance levels [13].

Table 1 Service quality dimensions and test result

\begin{tabular}{|c|c|c|c|}
\hline Dimensions & $\begin{array}{c}\mathrm{r} \\
\text { arithmetic }\end{array}$ & $\begin{array}{c}\mathbf{r} \\
\text { table }\end{array}$ & $\begin{array}{c}\text { Cronbach } \\
\alpha\end{array}$ \\
\hline Check-in (CHK) & & \multirow{16}{*}{0.098} & \multirow{16}{*}{0.906} \\
\hline Officer service (CHK1) & 0.731 & & \\
\hline Check-in process efficiency (CHK2) & 0.719 & & \\
\hline Convenience (CON) & & & \\
\hline $\begin{array}{l}\text { Availability of restaurant and minimart } \\
\text { (CON1) }\end{array}$ & 0.659 & & \\
\hline $\begin{array}{l}\text { Availability of disabled special toilet and } \\
\text { elderly (CON2) }\end{array}$ & 0.402 & & \\
\hline Availability of breastfeeding room (CON3) & 0.380 & & \\
\hline $\begin{array}{l}\text { Courtesy and helpfulness of railway station } \\
\text { staff (CON4) }\end{array}$ & 0.709 & & \\
\hline Feeling of being safe and secure (CON5) & 0.585 & & \\
\hline \multicolumn{2}{|l|}{ Basic Facilities (BAS) } & & \\
\hline Departure lounge facilities (BAS1) & 0.696 & & \\
\hline Cleanliness of toilets (BAS2) & 0.656 & & \\
\hline Cleanliness of mosque (BAS3) & 0.659 & & \\
\hline Parking area facilities (BAS4) & 0.420 & & \\
\hline \multicolumn{2}{|l|}{ Ambience (AMB) } & & \\
\hline $\begin{array}{l}\text { Cleanliness of railway station facilities } \\
\text { (AMB1) }\end{array}$ & 0.501 & & \\
\hline Neatness of spatial arrangement (AMB2) & 0.591 & & \\
\hline
\end{tabular}




\section{Result and discussion}

\subsection{Visitors distribution}

Table 2 displays the descriptive analysis of the demographic profile of respondents, of whom 54.8\% were men. A large number of respondents are from the age 18-24 (62.3\%). Most participants received a monthly income of below Rp 500 (42\%).

\subsection{Validity and reliability analysis}

The reading of Cronbach's alpha and composite reliability for each service dimensions variable is greater than 0.70 , in relation to the expected factors, indicating higher reliability among the indicators. The r-arithmetic, as presented in Table 1, is greater than the r-table. It indicates that each variable is valid.

Table 2 Demographic profile of respondents

\begin{tabular}{|c|c|c|c|}
\hline Variables & & Frequency & Percentage \\
\hline \multirow[t]{2}{*}{ Gender } & Male & 181 & 45.3 \\
\hline & Female & 219 & 54.8 \\
\hline Age & $<18$ & 62 & 15.5 \\
\hline \multirow[t]{5}{*}{ (years old) } & $18-24$ & 249 & 62.3 \\
\hline & $25-34$ & 38 & 9.50 \\
\hline & $35-44$ & 14 & 3.50 \\
\hline & $45-54$ & 10 & 2.5 \\
\hline & $>54$ & 6 & 1.5 \\
\hline \multirow[t]{6}{*}{ Education level } & Elementary & 3 & 0.8 \\
\hline & Junior High School & 41 & 10.3 \\
\hline & Senior High School & 103 & 25.8 \\
\hline & Diploma & 35 & 8.8 \\
\hline & Undergraduate & 201 & 50.3 \\
\hline & Master/PhD & 15 & 3.8 \\
\hline $\begin{array}{l}\text { Monthly } \\
\text { income }\end{array}$ & $<\operatorname{Rp} 500$ & 168 & 42.0 \\
\hline \multirow[t]{6}{*}{ (thousands) } & Rp 500 - Rp 1.000 & 100 & 25.0 \\
\hline & Rp 1.000 - Rp 1.500 & 30 & 7.5 \\
\hline & Rp 1.500 - Rp 2.500 & 45 & 11.3 \\
\hline & Rp 2.500 - Rp 5.000 & 50 & 12.5 \\
\hline & Rp 5.000 - Rp 7.500 & 7 & 1.8 \\
\hline & $>\operatorname{Rp} 7.500$ & 0 & 0 \\
\hline
\end{tabular}




\subsection{Regression analysis}

Regression analysis result presents five services items and one passenger characteristic variables with significance statistic at 0.1 level. (Table 2). According to the test, the model was fitted with logistic function at a 0.05 significance level.

Table 2. Parameter estimation

\begin{tabular}{|l|l|l|l|l|l|}
\hline & & Estimate & Std. error & Wald & Sig. \\
\hline Threshold & overall $=2.00$ & 2.964 & 1.112 & 7.103 & 0.008 \\
\hline & overall $=3.00$ & 7.505 & 1.193 & 39.552 & 0.000 \\
\hline Location & CON1 & 0.372 & 0.197 & 3.593 & 0.058 \\
\hline & CON4 & 0.522 & 0.278 & 3.526 & 0.060 \\
\hline & CON5 & 0.389 & 0.197 & 3.907 & 0.048 \\
\hline & BAS1 & 0.554 & 0.204 & 7.368 & 0.007 \\
\hline & BAS4 & 0.282 & 0.146 & 3.744 & 0.053 \\
\hline & Gender & -0.625 & 0.241 & 6.722 & 0.010 \\
\hline
\end{tabular}

p-value $<0.01 ; R^{2}$ Cox and Snell 0.185; $\mathrm{R}^{2}$ Negelkerke 0.224; $\mathrm{R}^{2}$ McFadden 0.117

The following general estimated equation was obtained: Logit $=a_{j}-[+0.372(C O N 1)$ $+0.522(\mathrm{CON} 4)+0.389(\mathrm{CON} 5)+0.554(\mathrm{BAS} 1)+0.282(\mathrm{BAS} 4)-0.625($ gender $)]$. Where a 2 $=2.964, \mathrm{a} 3=7.505$ are the values for the intercepts $\mathrm{a}$ j.

\subsection{Direction of the Effects}

According to the results, passengers are more likely to assign higher ranking for overall satisfaction with the railway station the getting higher his level of satisfaction with service items. These items are "Availability of restaurant and minimart (CON1)", "Courtesy and helpfulness of railway station staff (CON4)", "Feeling of being safe and secure (CON5)", "Departure lounge facilities (BAS1)", "Parking area facilities (BAS4)". These service items have positive effect, it indicates that the higher his/her satisfaction with these service items, the more likely the passenger assign a higher rating for overall satisfaction.

The non-significant effect items such as "Check-in dimensions" and "Ambience" indicate that the attributes may be generally a minor concern for passengers at railway station. Cleanliness of toilets and mosque should be the significant factor that effects the overall satisfaction. It is particularly interesting, considering the fact that cleanliness of toilet is one of the main criteria for passenger. The cleanliness of toilet is the highest value of weight in the cleanliness primary indicator [3].

Regarding the passenger characteristics, gender presented the significant effect. Gender has a negative effect on overall satisfaction. It indicates that the coding 1 (male), more likely to present a higher overall satisfaction.

\section{Conclusions}


The focus of research in railway station service quality has been published little on the perspective of railway station passengers especially in Asian country, include Indonesia. This study is a small piece of contribution for the development of a broader understanding of railway station service quality form perspective of passenger. The thirteen service items extracted from Guidelines for Standardization of Railway Stations provide a representative framework of how passengers evaluate railway station service quality. This study illustrates how the probabilistic approach may be used for the direction of the effects of service quality and passengers' characteristics on the probability that a passenger presents higher level of overall satisfaction.

Considering future works, earliness of arrival and trip purpose should be analyzed, regarding the earliness of arrival has a positive effect on overall satisfaction of airport services quality [10]. Furthermore, although several variables has proved to be valid, railway service quality dimension should be built from a deeper passenger behavior and expectations. Opportunities exist to further advance this research by expanding the number of variables, investigate at different location, and multiplying number of respondents since the questionnaire only distribute among 400 respondents.

\section{Acknowledgements}

We thank PT KAI DAOP IX Jember for granting access to the dataset and giving permission to distribute the questionnaires at Jember Railway Station.

\section{References}

1. Brady, Michael K., J.Joseph Jr. Cronin, Tim Brady, Michael K. Brady, and J.Joseph Jr. Cronin. "Some New Thoughts on Conceptualizing Perceived Service Quality: A Hierarchical Approach." The American Avation Experience 65(3):34-49. Retrieved (http://journals.ama.org/doi/abs/10.1509/jmkg.65.3.34.18334). (2001).

2. Oliver, Richard L. "Satisfaction: A Behavioral Perspective on the Consumer." Journal of Consumer Marketing 14:448. Retrieved (http://www.amazon.com/SatisfactionBehavioral-Perspective-McGraw-Hill-marketing/dp/0071154124). (1997).

3. Eboli, Laura, Yanbing $\mathrm{Fu}$, and Gabriella Mazzulla. "Multilevel Comprehensive Evaluation of the Railway Service Quality.” Procedia Engineering 137:21-30.( 2016).

4. Kumar, P.Vima. and P. Jitin. "A Study on Passengers' Satisfaction towards Railway Service With Reference To Coimbatore Junction." International Journal of Management and Commerce Innovations 2(2):578-82. (2014).

5. Ekinci, Yuksel. "From Destination Image to Destination Branding: An Emerging Area of Research." E-Review of Tourism Research 1(2):21-24. Retrieved (http://ertr.tamu.edu). (2003).

6. Rust, Roland T. and Richard L. Oliver. "Service Quality: Insights and Managerial Implications from the Frontier." Pp. 1-19 in Service Quality: New Directions in Theory and Practice. (1994).

7. Wilson, A., V. A. Zeithaml, M. J. Bitner, and D. D. Gremler. "Services Marketing: Integrating Customer Focus across the Firm." Pp. 338-65 in Services marketing: integrating customer focus across the firm. (2012). 
8. Ghozali, Imam. “Aplikasi Analisis Multivariate Dengan Program IBM Dan SPSS." in aplikasi analisis multivariate dengan program ibm spss 19. (2011).

9. Akinci, Serkan, Erdener Kaynak, Eda Atilgan, and Safak Aksoy. Where Does the Logistic Regression Analysis Stand in Marketing Literature?: A Comparison of the Market Positioning of Prominent Marketing Journals. Retrieved (http://www.emeraldinsight.com/10.1108/03090560710737598). (2007).

10. Bezerra, George C. L. and Carlos F. Gomes. "The Effects of Service Quality Dimensions and Passenger Characteristics on Passenger's Overall Satisfaction with an Airport." Journal of Air Transport Management 44-45:77-81. Retrieved (http://dx.doi.org/10.1016/j.jairtraman.2015.03.001). (2015).

11. Nickerson, Raymond S. "Null Hypothesis Significance Testing: A Review of an Old and Continuing Controversy." Psychological Methods 5(2):241-301. (2000).

12. Gelman, Andrew and Hal Stern. "The Difference Between 'Significant' and 'Not Significant' Is Not Itself Statistically Significant.” The American Statistician 60(4):32831. (2006).

13. Figueiredo Filho, Dalson Britto et al. "When Is Statistical Significance Not Significant?" Brazilian Political Science Review 7(1):31-55. Retrieved (http://www.bpsr.org.br/index.php/bpsr/article/view/154). (2013).

14. Hair, Joseph F., William C. Black, Barry J. Babin, and Rolph E. Anderson. “Multivariate Data Analysis." Vectors 816. (2010). 